\title{
Quality of raw milk from a farm with automatic milking system in the Czech Republic
}

\author{
Bohumíra Janštová, Michaela Dračková, Kateřina Dlesková, Šárka Cupáková, \\ Lenka Necidová, Pavlína Navrátilová, Lenka Vorlová
}

\begin{abstract}
Department of Milk Hygiene and Technology, Faculty of Veterinary Hygiene and Ecology, University of Veterinary and Pharmaceutical Sciences, Brno, Czech Republic
\end{abstract}

Received March 2, 2010

Accepted October 26, 2010

\begin{abstract}
The aim of this study was to assess the quality of raw cow's milk from an automatic milking system. Samples of milk (48) were analyzed chemically and microbiologically and the somatic cell count, freezing point and inhibitor residues were determined. For comparison purposes, milk analysis data from two farms using conventional machine milking and 2008 milk analysis report data for the Czech Republic were used. All physical and chemical characteristics of the study samples were within the established limits. The average content (\%) of chemical indicators was following: fat $3.79 \pm 0.18$, protein $3.46 \pm 0.06$, casein $2.67 \pm 0.09$, lactose $4.82 \pm 0.04$ and NFS $8.96 \pm 0.11$. The values for freezing point and somatic cells count were $221 \pm 46.10^{3} \cdot \mathrm{ml}^{-1}$ and $-0.521 \pm 0.003{ }^{\circ} \mathrm{C}$ respectively. No inhibitor residue was detected in any of the samples. Microbiological values were lower than the limits: the total microbial count $\left(2.3 \cdot 10^{4} \mathrm{CFU} \cdot \mathrm{ml}^{-1}\right)$, psychrotrophic count $\left(6.3 \cdot 10^{3} \mathrm{CFU} \cdot \mathrm{ml}^{-1}\right)$, coliform count $\left(2.4 \cdot 10^{1} \mathrm{CFU} \cdot \mathrm{ml}^{-1}\right)$, Escherichia coli count $\left(3.2 \cdot 10^{1} \mathrm{CFU} \cdot \mathrm{ml}^{-1}\right)$, enterococci count $\left(8.5 \cdot 10^{1} \mathrm{CFU} \cdot \mathrm{ml}^{-1}\right)$ and Staphylococcus aureus count $\left(1.1 \cdot 10^{1} \mathrm{CFU} \cdot \mathrm{ml}^{-1}\right)$. The study provides a comprehensive view on the quality of milk produced by robotic milking. The automatic milking system seems to be excellent in terms of milking and milk hygiene.
\end{abstract}

Robotic milking, somatic cells, freezing point, microbiology

The production of high quality milk and keeping the herd in good health are the main objectives in primary milk production. A milking robot - automatic milking system (AMS) seems to be a possible solution to meet these objectives.

Some authors have reported a $10-15 \%$ milk yield increase, e.g. Wade et al. (2004) found the milk yield to be $12.4 \%$ higher, but others such as Billon and Touraine (2002) have observed, in contrast, milk yield reduction. Klungel et al. (2000), Rasmussen et al. (2002), de Koning et al. (2003), Svennersten-Sjaunja and Pettersson (2008) have reported AMS to have negative effects on milk indicators such as increase in the freezing point, in the total microbial count, in the free fatty acid content or in the somatic cell count. Klei et al. (1997) have found more frequent milking in AMS (3 times a day) to result in lower milk fat and protein contents. Others, e.g. Nielen et al. (1992) have reported positive effects of AMS on milk quality, more precisely lower incidence of pathogens, particularly of Staphylococcus aureus, a common cause of mastitis in dairy cow.

In keeping with automatic milking system, a low prevalence of mastitis in cows were found, therefore the aim of the study was to test milk from automatic milking system for physical and chemical properties, focusing on the somatic cell count and freezing point, and a broad spectrum of microbiological indicators. The results of our study can be with the values obtained by conventional machine milking systems on the farms with higher incidence of mastitis and also with the milk quality report for the Czech Republic in 2008. 


\section{Materials and Methods}

Raw cow's milk samples were collected from a Czech farm that uses the automatic milking system (AMS) Lely Astronaut Evolution (The Netherlands).

In total, 48 bulk tank milk samples from second to third lactation Holstein cows were collected and analyzed. The milk samples were collected four times a month for one calendar year. They were added the preservative Broad Spectrum Microtabs ${ }^{\circledR}$ II (D\&F Control Systems, Inc., California, USA), except for those intended for freezing point determination and microbiological analysis. After cold transport to the laboratory $\left(<10{ }^{\circ} \mathrm{C}\right)$, the samples were analysed within $24 \mathrm{~h}$ according to the respective standards (see below).

The following selected physical and chemical properties of milk were monitored: fat, proteins, casein, lactose, non-fat solids, freezing point, titratable acidity, somatic cell count and inhibitor residues. Milk composition was determined in compliance with Czech standard ČSN 570536 (1999) using a Bentley 2500 analyzer (Bentley Instruments, Minnesota, USA). The somatic cell count (SCC) was determined by flow cytometry using the fluoroopto-electronic method in compliance with Czech standard EN ISO 13366-3:1998, with a Bentley Somacount 500 (Bentley Instruments, USA). The freezing point (FP) determination was carried out in compliance with Czech standard ČSN 570538 (1998) using a Funke Gerber Freezing point determiner CryoStar automatic 7160 (Funke Gerber, Germany). The instruments were regularly calibrated and tested for analytical performance. Titratable acidity was determined according to Czech standard ČSN 570530 (2006).

The following microbiological indicators were determined: total microbial count (ČSN EN ISO 4833:2003), psychrotrophic count (ČSN ISO 17410:2003), coliform count (ČSN ISO 4832:1995), Escherichia coli count (CSN ISO 16649-2:2003), enterococcus count - $0.2 \mathrm{ml}$ of the sample streaked onto Slanetz and Bartley agar (Oxoid, Basingstoke, UK) and cultured aerobically at $37^{\circ} \mathrm{C}$ for $48 \mathrm{~h}$, and Staphylococcus aureus count ( $\breve{\mathrm{CSN}} \mathrm{EN}$ ISO 6888-1:2004).

The obtained data were compared with the respective results from analysis of bulk tank milk samples from second to third lactation Holstein cows fed with similar rations, from two Czech farms using conventional milking systems, CMS A $(n=48)$ and CMS B $(n=48)$. The number of dairy cows in all farm was similar. Furthermore, the obtained data were compared with the 2008 nationwide data (2008-CZ) from the annual report entitled Cattle farming in the Czech Republic -the main indicators and results 2008 (Kvapilík et al. 2009).

Stat plus software (Matoušková et al. 1992) served for statistical analysis and paired $t$-test was used for the calculation of significance of differences $(P=0.01, P=0.05)$ between milk indicators from AMS vs CMS A, AMS vs CMS B and AMS vs 2008-CZ.

\section{Results and Discussion}

The AMS milk composition and physical and chemical properties are presented in Table 1. The average content $(\%)$ of chemical properties was following: fatt $3.79 \pm 0.18$, protein $3.46 \pm 0.06$, casein $2.67 \pm 0.09$, lactose $4.82 \pm 0.04$ and NFS $8.96 \pm 0.11$.

Table 1. Physical and chemical properties of milk from the automatic milking system (AMS)

\begin{tabular}{lcccccccc}
\hline Indicator & $\begin{array}{c}\text { Fat } \\
(\%)\end{array}$ & $\begin{array}{c}\text { Protein } \\
(\%)\end{array}$ & $\begin{array}{c}\text { Casein } \\
(\%)\end{array}$ & $\begin{array}{c}\text { Lactose } \\
(\%) \mathrm{S}\end{array}$ & $\begin{array}{c}\text { NF } \\
(\%)\end{array}$ & $\begin{array}{c}\text { Titratable } \\
\text { acidity } \\
(\mathrm{SH})\end{array}$ & $\begin{array}{c}\text { SCC } \\
(\text { per ml })\end{array}$ & $\begin{array}{c}\text { FP } \\
\left({ }^{\circ} \mathrm{C}\right)\end{array}$ \\
\hline $\mathrm{x}$ & 3.79 & 3.46 & 2.67 & 4.82 & 8.96 & 6.93 & $221 \cdot 10^{3}$ & -0.521 \\
$\min$ & 3.64 & 3.42 & 2.50 & 4.76 & 8.90 & 6.75 & $171 \cdot 10^{3}$ & -0.517 \\
$\max$ & 4.02 & 3.56 & 2.72 & 4.89 & 9.11 & 7.20 & $327 \cdot 10^{3}$ & -0.526 \\
$\mathrm{SD}$ & 0.18 & 0.06 & 0.09 & 0.04 & 0.11 & 0.28 & $46 \cdot 10^{3}$ & 0.003 \\
\hline
\end{tabular}

NFS - non-fat solids, SCC - somatic cell count, FP - freezing point

Klungel et al. (2000) have found the milk composition, particularly the fat and protein contents, to depend on the milking frequency and milking system. They have reported a higher milk fat content $(4.43 \%$ vs $4.37 \%)$ and higher milk protein content $(3.49 \% \mathrm{vs}$ $3.42 \%$ ) before the introduction of AMS. Klungel et al. (2000), de Koning et al. (2003) and Abeni et al. (2005) also found milk from AMS to be higher in free fatty acids (FFA). Abeni et al. (2005) have reported milk from AMS to have less natural creaming.

The Czech National Standard ČSN 570529 (1993) for raw cow's milk for dairy treatment and processing lays down the following limits: not less than $33.0 \mathrm{~g} \cdot \mathrm{l}^{-1}$ for the fat content, 
$28.0 \mathrm{~g} \cdot \mathrm{l}^{-1}$ for the protein content $\left(32.0 \mathrm{~g} \cdot \mathrm{l}^{-1}\right.$ for milk for sale), $8.5 \%$ for the non-fat solids (NFS) content and 6.2-7.8 SH for titratable acidity. From our results it follows that all the study samples complied with these requirements.

The mean somatic cell count (SCC) was $221 \pm 46 \cdot 10^{3} \cdot \mathrm{ml}^{-1}$ (range from 171 to $237 \cdot 10^{3} \cdot \mathrm{ml}^{-1}$ ). As Regulation No. $1662 / 2006$ (2006) amending Regulation No. $853 / 2004$ (2004) of the European Parliament and of the Council lays down the limit for the somatic cell count of $400,000 \cdot \mathrm{ml}^{-1}$, it can be concluded that in all the collected samples, SCC was about half the limit and thus conforms to the applicable regulation, including the highest value of $237 \cdot 10^{3} \cdot \mathrm{ml}^{-1}$. Š karda et al. (1990) report SCC to range between 5,000 and $100,000 \cdot \mathrm{ml}^{-1}$ in milk of healthy first calvers and between 20,000 and $200,000 \cdot \mathrm{ml}^{-1}$ in milk of older dairy cows. Somatic cell count decreases with the increasing level of zoohygienic conditions, dairy cow health and welfare and milking conditions. Efforts should be made to keep SCC as low as $80,000-100,000 \cdot \mathrm{ml}^{-1}$ or even lower, since the allowable limit of $400,000 \cdot \mathrm{ml}^{-1}$ still indicates that a considerably high percentage of subliclinical mastitis occurs in the herd (Kadlec 1997). Rasmussen et al. (2002) have reported that studies from several countries found higher SCC in milk after the implementation of robotic milking due to increase in new infections. In another study, Rasmussen et al. (2001) monitored the quality of milk during one year before and during one year after the implementation of AMS. They found increase in SCC after the implementation of AMS, particularly in the first three months. On the other hand, Klungel et al. (2000) have reported a non-significant reduction in SCC from $233 \cdot 10^{3} \cdot \mathrm{ml}^{-1}$ to $217 \cdot 10^{3} \cdot \mathrm{ml}^{-1}$ after the implementation of AMS.

The mean freezing point (FP) was $-0.521 \pm 0.003{ }^{\circ} \mathrm{C}$ (range from -0.526 to $-0.517{ }^{\circ} \mathrm{C}$ ), with three samples showing higher values than $\leq-0.520{ }^{\circ} \mathrm{C}$, i.e. than the generally accepted limit laid down by CSN 570529 (1998). This slight increase might be caused by a range of factors, given that FP is $75-80 \%$ modifiable by milk lactose and chlorides and the remaining 20-25\% depend on milk calcium, magnesium, lactates, citrates, urea, etc. (Fox and McSweeney 1998). Based on the analysis of 234 milk samples, Buchberger (1996) has found a significant negative dependence between FP and milk lactose and urea contents. Freezing point was higher in the samples lower in lactose and proteins. Many authors have confirmed increase in FP of milk extracted by AMS due to higher milk water content. For instance, Klungel et al. (2000) have reported a slight increase in FP in their study of the impact of robotic milking on the quality of milk on 28 farms. As a possible explanation for the reported increase of FP from $-0.520{ }^{\circ} \mathrm{C}$ to $-0.517{ }^{\circ} \mathrm{C}$ they suggest a higher milk water content resulting from more frequent cleaning of the system. When comparing the quality of milk before and after the implementation of AMS, Rasmussen et al. (2001) also found increase in FP, peaking in the first three months after the implementation of AMS.

The milk composition (fat, protein, lactose, non-fat solids) data for the AMS and conventional milking systems CMS A and CMS B and the 2008 milk analysis report data for the Czech Republic (2008-CZ) (Kvapilík et al. 2009) are compared in Fig. 1.

As can be seen from Fig. 2, SCC was lower in milk from AMS $\left(221 \cdot 10^{3} \cdot \mathrm{ml}^{-1}\right)$ than in that from CMS A $\left(242 \cdot 10^{3} \cdot \mathrm{ml}^{-1}\right)$, but the difference was not significant. Contrarily, significant differences in SCC were found between milk from AMS $\left(221 \cdot 10^{3} \cdot \mathrm{ml}^{-1}\right)$ and that from CMS B $\left(330 \cdot 10^{3} \cdot \mathrm{ml}^{-1}\right)$ and the $2008-\mathrm{CZ}$ data $\left(262.3 \cdot 10^{3} \cdot \mathrm{ml}^{-1}\right),(P=0.01$ and $P=0.05)$.

The freezing point of $-0.522{ }^{\circ} \mathrm{C}$ determined for milk from AMS was higher $(P=0.01)$ as compared with those from other farms, i.e. $-0.526{ }^{\circ} \mathrm{C}$ for $\mathrm{CMS} \mathrm{A},-0.526{ }^{\circ} \mathrm{C}$ for $\mathrm{CMS}$ $\mathrm{B}$, and $-0.527^{\circ} \mathrm{C}$ for $2008-\mathrm{CZ}$, which is consistent with the findings of Klungel et al. (2000).

Inhibitor residues were not found in any of the milk samples. It is suggestive of adherence 


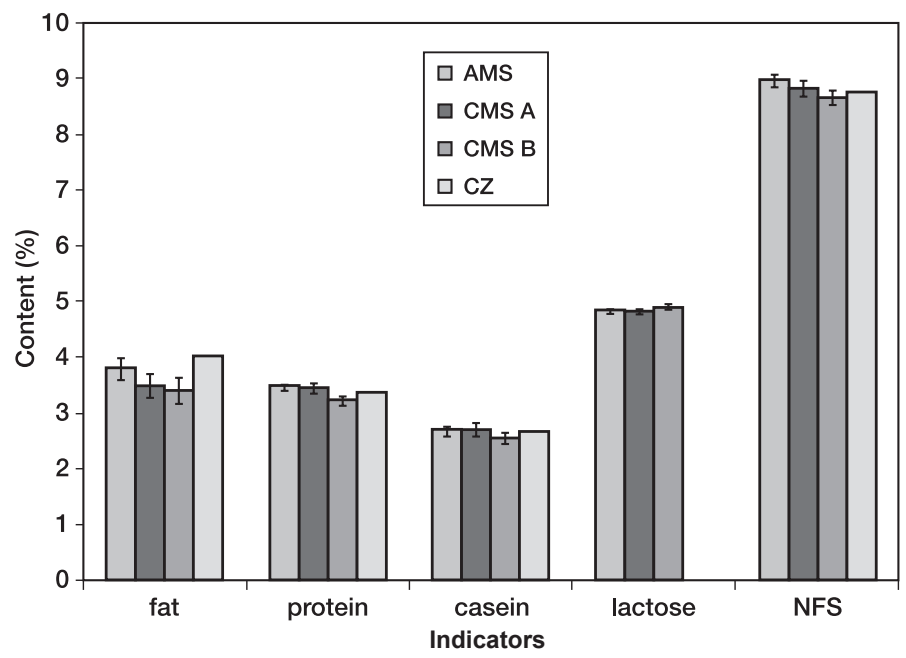

Fig. 1. Comparison of milk composition data from a farm using the automatic milking system (AMS), two farms using the conventional milking system (CMS A, CMS B) and the 2008-CZ report

NFS- non-fat solids, AMS- automatic milking system, CMS A - conventional milking system - farm A, CMS B conventional milking system - farm B, CZ - Czech republic

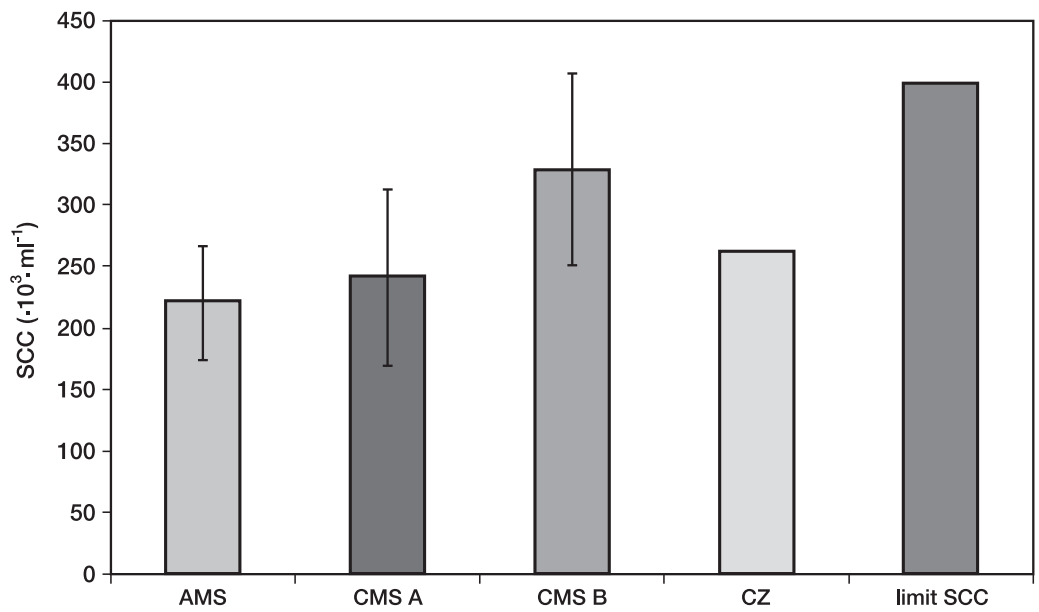

Fig. 2. Comparison of the somatic cell count in milk from a farm using the automatic milking system (AMS), two farms using the conventional milking system (CMS A, CMS B) and the 2008-CZ report

AMS- automatic milking system, CMS A - conventional milking system - farm A,

CMS B - conventional milking system - farm B, CZ - Czech republic, limit SCC - limit somatic cells count

to withdrawal times of veterinary drugs and removal of the treated dairy cows from milk production. The detection rate of inhibitor positive samples in the Czech Republic in 2008 was $0.12 \%$ (Kvapilík et al. 2009).

Table 2 shows the microbiological quality of milk which is very good and Fig. 3 compares the data obtained for milk from AMS, CMS A, CMS B and some 2008-CZ report indicators (Kvapilík et al. 2009). 
Table 2. Microbiological properties of milk from the automatic milking system (AMS)

\begin{tabular}{lcccrrr}
\hline $\begin{array}{l}\text { Indicator } \\
\left(\mathrm{CFU} \cdot \mathrm{ml}^{-1}\right)\end{array}$ & $\begin{array}{c}\mathrm{SPC} \\
\left(\mathrm{CFU} \cdot \mathrm{ml}^{-1}\right)\end{array}$ & $\begin{array}{c}\mathrm{PPC} \\
\left(\mathrm{CFU} \cdot \mathrm{ml}^{-1}\right)\end{array}$ & $\begin{array}{c}\mathrm{CC} \\
\left(\mathrm{CFU} \cdot \mathrm{ml}^{-1}\right)\end{array}$ & $\begin{array}{c}\text { E. coli } \\
\left(\mathrm{CFU} \cdot \mathrm{ml}^{-1}\right)\end{array}$ & $\begin{array}{c}\text { ENT } \\
\left(\mathrm{CFU} \cdot \mathrm{ml}^{-1}\right)\end{array}$ & S. aureus \\
$\mathrm{x}$ & $2.3 \cdot 10^{4}$ & $6.3 \cdot 10^{3}$ & $2.4 \cdot 10^{1}$ & $3.2 \cdot 10^{1}$ & $8.5 \cdot 10^{1}$ & $1.1 \cdot 10^{1}$ \\
\hline $\min$ & $1.2 \cdot 10^{4}$ & $3.0 \cdot 10^{3}$ & $8.0 \cdot 10^{1}$ & $<5.0 \cdot 10^{1}$ & $1.1 \cdot 10^{1}$ & $<5.0 \cdot 10^{1}$ \\
$\max$ & $3.8 \cdot 10^{4}$ & $1.2 \cdot 10^{4}$ & $8.8 \cdot 10^{2}$ & $9.9 \cdot 10^{1}$ & $3.5 \cdot 10^{2}$ & $6.2 \cdot 10^{1}$ \\
\hline
\end{tabular}

SPC - standard plate count, PPC - psychrotrophic plate count, CC - coliform count,

E. coli - Escherichia coli count, ENT- enterococcus count, S. aureus - Staphylococcus aureus count

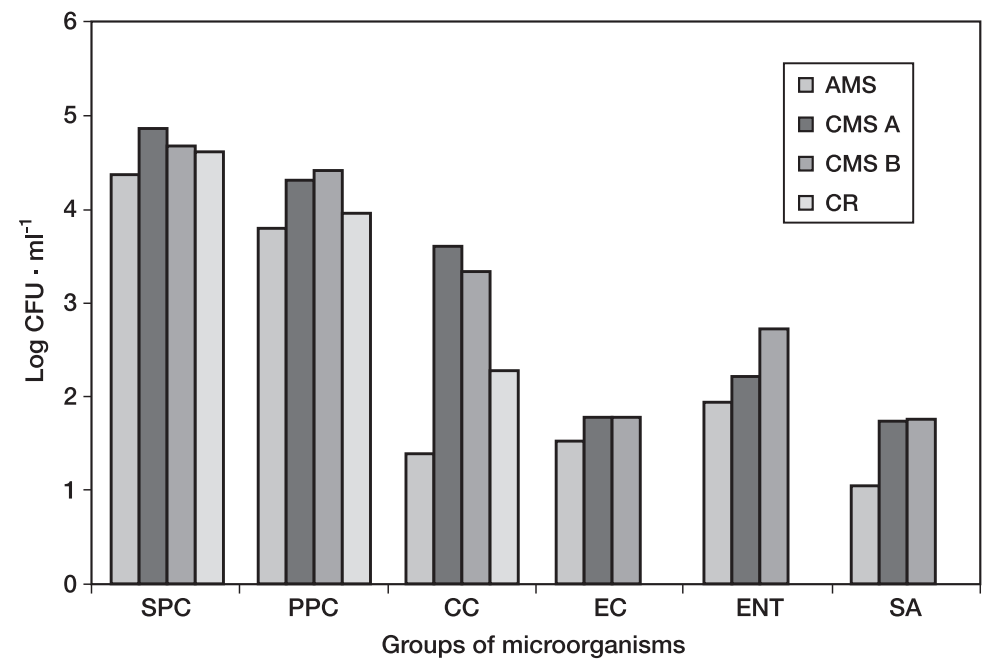

Fig. 3. Comparison of milk microbiological quality data from a farm using an automatic milking system (AMS), two farms using a conventional milking system (CMS A, CMS B) and the 2008-CZ report

SPC - standard plate count, PPC - psychrotrophic plate count, CC - coliform count,

E. coli - Escherichia coli count, ENT- enterococcus count, S. aureus - Staphylococcus aureus count, AMSautomatic milking system, CMS A - conventional milking system - farm A,

CMS B - conventional milking system - farm B, CZ - Czech republic

The standard plate count (SPC) was in the range of the order of $10^{4} \mathrm{CFU} \cdot \mathrm{ml}^{-1}$ throughout the year, with an average of $2.3 \cdot 10^{4} \mathrm{CFU} \cdot \mathrm{ml}^{-1}$ which is considerably lower than the limit laid down by Regulation (EC) No. 853/2004 of the European Parliament and of the Council (1662/2006, CSN 570529 1993), i.e. 100,000 CFU· $\mathrm{ml}^{-1}$, calculated as the two-month moving geometric mean for at least two samples per month. It is also clearly lower than SPC for the milk from CMS A $\left(7.3 \cdot 10^{4} \cdot \mathrm{ml}^{-1} ; P=0.01\right), \mathrm{CMS} \mathrm{B}\left(4.8 \cdot 10^{4} \cdot \mathrm{ml}^{-1} ; P=0.01\right)$ and the country-wide $2008-\mathrm{CZ}$ data $\left(4.03 \cdot 10^{4} \cdot \mathrm{ml}^{-1} ; P=0.05\right)$. This positive result mirrors primarily high adherence to good milking hygiene practices in the robotic milking system. The milking robot does the pre-milking teat brushing and milking cup cleaning in every milking session and also schedules regular thorough cleaning and disinfection of the whole milk piping including the bulk tanks. This all has a positive effect, since preventing the proliferation of microorganisms and subsequent contamination of milk. The separation of the first amount of extracted milk is also highly important. Similar data have been reported by Klungel et al. (2000) in their study of the impact of robotic milking on the quality of milk: they found a slight increase in SPC, followed by a plateau that causes no concern. Rasmussen et al. (2001) have observed a rise in SPC in the first three months after the implementation of AMS. The differences between our data and 
theirs are likely to arise from different zoohygienic conditions and AMS type used and the fact that AMS on the study farm has been in operation for several years.

The counts of other monitored microorganisms were also low. Some microorganisms adapted rapidly to the changed conditions in the cooling technology. Species that are predominantly mesophilic and thermophilic in natural ecosystems have created psychrotrophic biotypes capable of growing at low temperatures (McGuigann et al. 1994).

The psychrotrophic plate count (PPC) was $6.3 \cdot 10^{3} \mathrm{CFU} \cdot \mathrm{ml}^{-1}$, an increase to $10^{4} \mathrm{CFU} \cdot \mathrm{ml}^{-1}$ was observed in months 5 and 8. PPC accounted for $27 \%$ of SPC. In raw cow's milk, the PPC proportion in SPC varies widely depending on the level and type of contamination, temperature and storage time. Silveira et al. (1999) have reported $44 \%$ of psychrotrophic strains for a milk contamination level of $2.7 \cdot 10^{4} \mathrm{CFU} \cdot \mathrm{ml}^{-1}$. The limit laid down by Czech National Standards ČSN 570529 (1993) and ČSN 569601 (2006) is 50,000 CFU·ml-1.

The mean PPCs in milk found on farms with CMS were $1 \log$ higher, i.e. $2.1 \cdot 10^{4}$ $\mathrm{CFU} \cdot \mathrm{ml}^{-1}$ for CMS A and $2.6 \cdot 10^{4} \mathrm{CFU} \cdot \mathrm{ml}^{-1}$ for CMS B. The differences were highly significant $(P=0.01)$. PPC for the Czech Republic was $9.3 \cdot 10^{3} \mathrm{CFU} \cdot \mathrm{ml}^{-1}(P=0.05)$.

The mean coliform count (CC), indicative of fecal contamination, was $2.4 \cdot 10^{1} \mathrm{CFU} \cdot \mathrm{ml}^{-1}$ which is a 2-log lower count than the limit laid down by ČSN 570529 and ČSN 569601 (2006), i.e. $2.0 \cdot 10^{3} \mathrm{CFU} \cdot \mathrm{ml}^{-1}$, and the lowest $\mathrm{CC}$ was found in the winter months. CC in the milk from AMS was 2 log lower in comparison with CMS A $\left(4.0 \cdot 10^{3} \mathrm{CFU} \cdot \mathrm{ml}^{-1} ; P=0.01\right)$ and CMS B $\left(2.2 \cdot 10^{3} \mathrm{CFU} \cdot \mathrm{ml}^{-1} ; P=0.01\right)$ and $1 \mathrm{log}$ lower than that from the nationwide 2008-CZ data $\left(1.95 \cdot 10^{2} \mathrm{CFU} \cdot \mathrm{ml}^{-1} ; P=0.01\right)$.

The mean $E$. coli count was $3.2 \cdot 10^{1} \mathrm{CFU} \cdot \mathrm{ml}^{-1}$, with no sample testing positive for $E$. coli in month 12 . The differences in the $E$. coli count between farms were at the significance level of $P=0.01\left(6.0 \cdot 10^{1} \mathrm{CFU} \cdot \mathrm{ml}^{-1}\right.$ for CMS A and 5.9 $10^{1} \mathrm{CFU} \cdot \mathrm{ml}^{-1}$ for CMS B).

The mean enterococcus (ENT) count was $8.5 \cdot 10^{1} \mathrm{CFU} \cdot \mathrm{ml}^{-1}\left(6.6 \cdot 10^{1} \mathrm{CFU} \cdot \mathrm{ml}^{-1}\right.$ for $\mathrm{CMS}$ $\mathrm{A} ; P=0.05$ and $5.4 \cdot 10^{2} \mathrm{CFU} \cdot \mathrm{ml}^{-1}$ for $\left.\mathrm{CMS} \mathrm{B} ; P=0.01\right)$.

The mean $S$. aureus count was $1.1 \cdot 10^{1} \mathrm{CFU} \cdot \mathrm{ml}^{-1}$, range $<5.0 \cdot 10^{1}-6.2 \cdot 10^{1} \mathrm{CFU} \cdot \mathrm{ml}^{-1}$. The highest $S$. aureus count was found in month 8 in correlation with higher PPC and SPC. The differences in the $S$. aureus counts between AMS and CMS A $\left(5.4 \cdot 10^{1} \mathrm{CFU} \cdot \mathrm{ml}^{-1}\right)$ and CMS $\mathrm{B}\left(5.7 \cdot 10^{1} \mathrm{CFU} \cdot \mathrm{ml}^{-1}\right)$ were significant at the levels of $P=0.01$ and $P=0.05$, respectively.

The comparison of the E. coli, ENT and $S$. aureus counts in milk extracted by AMS, CMS A and CMS B showed lower bacterial counts (except for ENT) in the milk from AMS. Although the differences were of the order of $1 \log$ unit, they were significant at the above mentioned levels.

Moroni et al. (2002) who studied the incidence and spread of Staphylococcus aureus, a causative agent of mastitis, in relation to robotic milking concluded that the implementation of AMS reduces the spread of Staphylococcus aureus and thus increases milk quality. Although reporting a slight increase in bacterial counts in the first months after the implementation of AMS, Nielen et al. (1992) have not clearly revealed a negative effect of robotic milking on milk quality in their study where no incremental cases of mastitis were observed. Furthermore, they have reported AMS to be associated with a reduced incidence of mastitis caused by $S$. aureus (Nielen et al. 1992).

From our findings it follows that none of the determined results would pose a risk to the quality of milk. The automated milking system thus seems to be excellent in terms of milking and milk hygiene. Robotic milking also has the advantages of promoting good general health of animals and animal welfare and removing the labour.

\section{Kvalita mléka z farmy v České republice s automatizovaným systémem dojení}

Cílem práce bylo hodnocení bezpečnosti a kvality syrového kravského mléka získaného roboty - automatizovaným systémem dojení (AMS). U 48 vzorků mléka bylo provede- 
no chemické a mikrobiologické vyšetření, byl stanoven bod mrznutí a počet somatických buněk a sledována prrítomnost reziduí inhibičních látek. K porovnání zjištěných hodnot byly použity výsledky vyšetření mléka získaného ze dvou farem klasickým strojním dojením (CMS) a výsledky hodnocení mléka v České republice za rok 2008. Všechny fyzikálně-chemické ukazatele odpovídaly stanoveným limitům. Průměrné zjištěné hodnoty byly: tuk 3,79\% $\pm 0,18$, bílkoviny 3,46\% $\pm 0,06$, kasein $2,67 \% \pm 0,09$, laktóza $4,82 \% \pm 0,04$, STP $8,96 \% \pm 0,11$, počet somatických buněk $221 \pm 46 \cdot 10^{3} \cdot \mathrm{ml}^{-1}$, bod mrznutí $-0,521 \pm 0,003{ }^{\circ} \mathrm{C}$. U žádného vzorku nebyla zjištěna rezidua inhibičních látek. Z mikrobiologických výsledků byl významný nízký celkový počet mikroorganismů $\left(2,3 \cdot 10^{4} \mathrm{CFU} \cdot \mathrm{ml}^{-1}\right)$ i dalších sledovaných mikroorganismů: psychrotrofních $\left(6,3 \cdot 10^{3} \mathrm{CFU} \cdot \mathrm{ml}^{-1}\right)$, koliformních $\left(2,4 \cdot 10^{1} \mathrm{CFU} \cdot \mathrm{ml}^{-1}\right)$, Escherichia coli $\left(3,2 \cdot 10^{1} \mathrm{CFU} \cdot \mathrm{ml}^{-1}\right)$, enterokoků $\left(8,5 \cdot 10^{1} \mathrm{CFU} \cdot \mathrm{ml}^{-1}\right)$ a Staphylococcus aureus $\left(1,1 \cdot 10^{1} \mathrm{CFU} \cdot \mathrm{ml}^{-1}\right)$. Studie podává komplexní pohled na problematiku robotizovaného dojení, které se jeví vynikající zejména z hlediska hygieny získávání mléka a kvality mléka.

\section{Acknowledgement}

The work was supported by grant No. 6215712402 of the Ministry of Education, Youth and Sports of the Czech Republic (Veterinary aspects of food safety and quality).

\section{References}

Abeni F, Degano L, Calza F, Giangiacomo R, Pirlo G. 2005: Milk quality and automatic milking: fat globule size, natural creaming and lipolysis. J Dairy Sci 88: 35189-3529

Billon P, Touraine F 2002: Impact of automatic milking systems on milk quality and farm management: The French experience. In The First American Conference on Robotic Milking. Proc. Toronto, Canada. Wageningen Pers, Wageningen, The Netherlans: V59-V63

Buchberger J 1996: Some notes on milk freezing point. Výzkum v chovu skotu, 4, 23-25 (in Czech)

Commission Regulation (EC) No 1662/2006 of 6 November 2006 amending Regulation (EC) No 853/2004 of the European Parliament and of the Council of 29 April 2004 laying down specific hygiene rules for food of animal origin. Official Journal of the European Union, 2006, L 320: 1-10

ČSN ISO 4833 2003: Microbiology of food and animal feeding stuffs - Horizontal method for the enumeration of microorganisms - Colony-count technique at 30 degrees C. Prague, Czech Standardization Institute, $16 \mathrm{p}$.

CSN ISO 4832 1995: Microbiology - General guidance for the enumeration of coliforms - Colony count techniques. Prague, Czech Standardization Institute, $12 \mathrm{p}$.

ČSN EN ISO 6888-1 2004: Microbiology of food and animal feeding stuffs - Horizontal method for the enumeration of coagulase-positive staphylococci (Staphylococcus aureus and other species) - Part 1: Technique using Baird-Parker agar medium. Prague, Czech Standardization Institute, $16 \mathrm{p}$.

ČSN ISO 16649-2 2003: Microbiology of food and animal feeding stuffs - Horizontal method for the enumeration of $\beta$-D-glucuronidase-positive Escherichia coli - Part 2:Colony count technique at 44 degrees Celsius using 5-bromo-4-chloro-3-indolyl $\beta$-D-glucuronide. Prague, Czech Standardization Institute, 12 p.

ČSN ISO 17410 2003: Microbiology of food and animal feeding stuffs - Horizontal method

for the enumeration of psychrotrophic microorganisms. Prague, Czech Standardization Institute, $12 \mathrm{p}$.

ČSN 570529 1993: Raw cow milk for dairy treatment and processing. Prague, Czech Standardization Institute, $6 \mathrm{p}$.

ČSN 570529 1998: Raw cow milk for dairy treatment and processing. Prague, Czech Standardization Institute, $1 \mathrm{p}$.

ČSN 570530 2006: Methods for testing of milk and liquid milk products. Prague, Czech Standardization Institute, $100 \mathrm{p}$.

ČSN 569601 2006: Guides to good hygiene and manufacturing practice - Milk and milk products. Prague, Czech Standardization Institute, $23 \mathrm{p}$.

ČSN 570536 1999: Determination of milk composition by mid-infrared analyzer. Prague, Czech Standardization Institute, $12 \mathrm{p}$.

ČSN 570538 1998: Determination of freezing point of milk - Cryoscope method. Prague, Czech Standardization Institute, $6 \mathrm{p}$.

ČSN EN ISO 13366-3/1998: Milk - Enumeration of comatic cells - Fluoro-opto-electronic method. Prague, Czech Standardization Institute, $10 \mathrm{p}$.

de Koning K, Slaghuis B, van der Vorst Y 2003: Robotic milking and quality: Effects on bacterial count, somatic cell counts, freezing points and free fatty acids. Ital J Anim Sci 2: 219-299

Fox PF, McSweeney PLH 1998: Dairy Chemistry and Biochemistry. Thomson Science, London, pp. 443-447 
Kadlec I 1997. Jakost mléka a její stanovení (Milk quality and its determination - in Czech). Náš chov 1: $10-11$

Klei LR, Lynch JM, Barbano, MD, Oltenacu, PA, Lednor JA, Bandler DK 1997: Influence of milking three times a day on milk quality. J Dairy Sci 80: $427-436$

Klungel GH, Slaghuis BA, Hogeveen H 2000: The effect of the introduction of automatic milking systems on milk quality. J Dairy Sci 83: 1998-2003

Kvapilík J, Růžička Z, Bucek P 2009: Ročenka Chov skotu v České republice. Hlavní ukazatele a výsledky za rok 2008 (Annual report Cattle farming in the Czech Republic. The main indicators and results 2008 - in Czech). Českomoravská společnost chovatelů, Prague, Czech Republic, 96 p.

Matoušková O, Chalupa J, Cígler M, Hruška K 1992: STAT-Plus uživatelská př́ručka, verze 1.01. (STAT-Plus user's guide, version 1.01 - in Czech). Veterinary Research Institute, Brno, Czech Republic, 168 p.

McGuiggan JTM, Gilmour A, Lawrence LM 1994: Factors influencing the recovery of psychrotrophic, mesophilic and thermophilic Bacillus species from bulk raw milk. J Soc Dairy Technol 47: 111-116

Moroni P, Cattaneo M, Casula A, Ruffo G, Bronzo V 2002: First study on prevalence and control of Staph. aureus intramammary infections in an Italian dairy farm, with automatic milking system. Proceedings of the 1st North American Conference on Robotic Milking, pp. IV-60

Nielen M, Deluyker H, Schukken YH, Brand A 1992: Electrical conductivity of milk: measurement, modifiers and meta analysis of mastitis detection performance. J Dairy Sci 75: 606-614

Rasmussen MD, Justesen P, Blom JY, Nielsen LAH 2001: Udder health of cows milked automatically. Livest Prod Sci 72: 183-185

Rasmussen MD, Bjerring M, Justesen P, Jepsen L 2002: Milk quality on Danish farms with automatic milking systems. J Dairy Sci 85: 2869-2878

Regulation (EC) No 853/2004 of the European Parliament and of the Council of 29 April 2004 laying down specific hygiene rules for food of animal origin. Official Journal of the European Union, 2004, No. L. 139: $14-74$

Silveira IA, Carvalho EP, Teixeira D, Barrios BE 1999: Verification of the proteolytic and lipolytic activies of the microbial flora isolated from raw, refrigerated, type B milk. II. Psychrotrophic microorganisms. Rev Latinoam Microbiol 41: 85-88

Svennersten-Sjaunja KM, Pettersson G 2008: Pros and cons of automatic milking in Europe. J Anim Sci 86: $37-46$

Škarda J, Škardová O, Urbanová E 1990: Prevence a tlumení mastitid dojnic (Preventing and reducing mastitis in dairy cows - in Czech). Veterinářství 5: 243-251

Wade KM, van Asseldonk MAPM, Berensten PBM, Ouweltjes W, Hogeveen 2004: Economic efficiency of automatic milking systems with specific emphasis on increases in milk production. In Automatic Milking, a Berger Understanding. A. Meijering, H. Hogeveen and de Koning CJAM, ed. Wageningen Academic Publisher, Wageningen, The Netherlands, p. 62-67 